\title{
THE METHOD OF JUDGING FROM THE VERSES OF THE QUR'AN IN THE TAFSIR OF MAHMUD ZAMAKHSHARI
}

\author{
Sherzodjon Umaraliev \\ International Islamic Academy of Uzbekistan, \\ lecturer at the Department of Islamic Studies and ICESCO \\ Chair For the study of Islamic Civilization \\ 11, A.Kadiri, Tashkent, \\ 100011, Uzbekistan.
}

Article DOI: https://doi.org/10.36713/epra5748

\begin{abstract}
There are different approaches to the verses of the Qur'an in the four schools of jurisprudence and the two doctrinal doctrines of Ahl as-Sunnah wa'l-Jama'ah. Mahmud Al-Zamahshari's al-Kashshaf, which contains these interpretations, tells us the differences between the sects regarding the ruling verses. In particular, Mahmud Al-Zamahshari is known to have belonged to the Hanafi school of thought in accordance with the method of elucidating the ruling verses in his commentary. This article examines Al-Zamahshari's interpretation of the Hanafi method of ruling.
\end{abstract}

KEYWORDS: Fiqh, hadith, al-Al-Zamakhshari, al-Kashshaf, tafsir, usul al-fiqh, hanafi.

\section{INTRODUCTION}

Mahmud al-Zamahshari, who has become a leading scholar in various fields of Islamic science, is the author of several works on the science of jurisprudence. His commentary on Mukhtasari Quduri, one of the most authoritative books of the Hanafi school, is Sharh Mukhatasar al-Quduri fi furu 'al-fiqh al-Hanafiyya, Manasik al-Hajj, dedicated to the pilgrimage, and Dalla an-nashid and ar- raid fi ilmi al-faroiz, Shaqaiq an-Nu'man fi haqaiq anNu'man "about the life and work of Abu Hanifa, "Mujam al-Hudud" on the law of had and punishment in Islam. He also wrote Ruus al-masail fi al-fiqh, a comparative analysis of the rulings of the Hanafi and Shafi'i schools. Al-Zamahshari, who was well acquainted with Shafi'i jurisprudence, also wrote a work on the maturity of the Arabic language, Shafi' al-ay min kalam al-Shafi'i.

Al-Zamahshari, who is also well-versed in the science of jurisprudence, has a unique method of ijtihad in illuminating the rulings in his commentary, al-Kashshaf.

\section{PART OF THE TEXT}

Mahmud Al-Zamakhshari was born in 467/1075 in the village of Zamakhshar in Khorezm. The scholar's full name is Abul Qasim Muhammad ibn Umar ibn Muhammad ibn Ahmad Khorezmi AlZamakhshari and he belongs to the Hanafi school of jurisprudence [4: 343].

Mahmud Al-Zamakhshari nicknamed "Jarullah" (neighbor of Allah) because of his long stay was twice in Mecca between the status of Ibrahim and the water of Zam-zam. It was during this period that the scholar completed his work on the science of tafsir, al-Kashshaf.

The scholar studied tafsir, hadith, usul, fiqh, kalam, mantiq, philosophy and lexicography in Bukhara. After that, in Baghdad, he studied jurisprudence with the Hanafi jurist Hussein ibn Muhammad Al-Damaghani [7: 47].

\section{THE SCIENCE OF JURISPRUDENCE IN THE TIME OF AL-ZAMAKHSHARI}

The formation of sects ended in the fourth century AH, when Al-Zamakhshari was born, and the period of "taqlid" (imitation) began. In particular, there was a period in the Hanafi Madhhab when independent ijtihad was replaced by ijtihad on issues related to the madhhab. The fifth century $\mathrm{AH}$, created by Al-Zamakhshari, dates back to the time when the Hanafi school of thought (preference for one ruling over another) was active in its methods and principles. 


\section{MAHMUD AL-ZAMAKHSHARI'S MADHAB OF JURISPRUDENCE}

Abduhay Al-Laknawi considers AlZamakhshari to be one of the leading scholars of the Hanafi school [4: 343]. However, in al-Kashshaf, the scholar has given way to the views of other sects, and scholars have expressed differing views on his school of jurisprudence.

Evidence from those who emphasize belonging to the Hanafi school. The fact that Mahmud Al-Zamakhshari wrote a special work for Abu Hanifa's views, Shaqoiqu-n-Nu'man fi haqaqiun-Nu'man, shows that he had a high regard for Abu Hanifa. The scholar was also proud to belong to the Hanafi school and wrote the following poem:

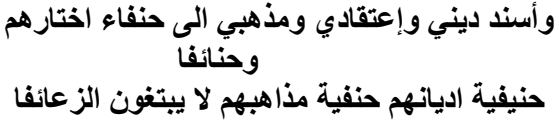

I rely on the Hanafis, who have chosen my religion, belief and sect as the Hanifs of Allah,

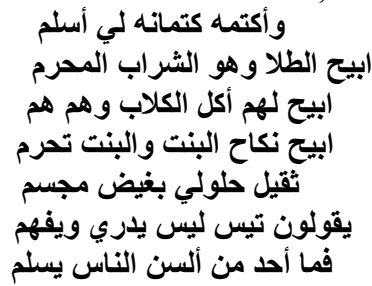

I did not state my sect when asked,

I keep it because keeping it is quieter for me, If I say I am a Hanafi, they say,

I consider the nabiz ${ }^{1}$ to be mubah, while it is haram.

If I say I am the owner, they say,

While I make it lawful to eat dog meat, it is (the dog) themselves.

If I say I am a chauffeur, they say, forbidden.

While I am permissible to marry a girl, it is

If I say I am Hanbali, they say,

I would be a critique of the sculpture, making it difficult to be honest.

If I say I am on the side of the people of hadith,

Woe is me! They say he knows nothing and does not understand.

I admire this time and its people,

No one is safe from the language of the people.

From this poem, it can be concluded that AlZamakhshari was not condemning sectarianism because of differences within sects, but that he was not prejudiced in addressing issues between sects. The fact that Al-Zamakhshari, as a faqih, did not

\footnotetext{
1 "Nabiz" is a jam in which dried fruits such as dates and raisins are soaked in water and consumed without turning into wine. If its time passes, it becomes a wine, that is, an intoxicating drink.
}

Their religion is Hanafi, their sect is Hanafi, and they do not pay attention to things that are useless and unnecessary [6: 91].

Evidence of those who emphasize belonging to the Shafi'i sect. Al-Zamakhshari respected Shafi'i as much as he respected Abu Hanifa and praised him as "Aimmatul Ulama" (Imam of the Scholars). The scholar wrote a book on the legacy of Shafi'i, entitled Shafi'ul ayn min kalami-sh-Shafi'i. Al-Zamakhshari also used Shafi'i views in some places in his commentary.

Evidence from those who insist that there is no prejudice in following a sect. Factors such as the prejudices of the jurisprudential sects during the time of Al-Zamakhshari, and the desire to prove that the evidence presented by one sect to another is incorrect, may have prompted the scholar to be careful in following a particular sect in jurisprudence. As proof of this, Al-Zamakhshari finished the following poem:

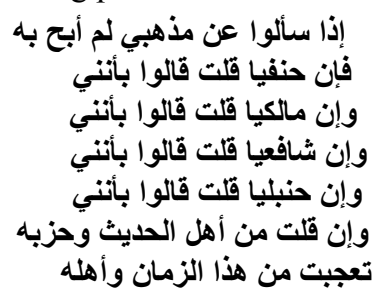

prefer the views of the four sects in the places he deemed necessary, shows that he preferred the sect to which he considered to be correct.

\section{JUDGMENT FROM THE VERSES IN AL-KASHSHAF}

In his commentary, Al-Zamakhshari did not mention the name of any source in his judgment of the rulings. Perhaps he quoted the views of the jurists on the subject.

The scholar referred to the hadiths many times in the play in order to support his opinion. These hadiths are suspended hadiths in which the names of the narrators are omitted. Of the hadith books, the author mentions only the Sahih of Muslim and the Sunan of Abu Dawud. Although he did not cite the source of the hadiths, Al-Zamakhshari was weak or the subject emphasized the hadiths.

Al-Kashshaf can be considered both a narrative and a mental commentary. In particular, in his commentary on verses on jurisprudential topics, the author not only narrates the views of his predecessors, but also mentions his personal ijtihad on the subject and mentally interprets it.

Al-Zamakhshari did not mention the source of the views of the faqihs he cited in his coverage of jurisprudential topics. In quoting the evidence, he first refers to the views of the Hanafis, and then the imams of other sects turn to the fatwas [3: 18]. Sometimes he emphasizes the judgment he has interpreted among the sects, and sometimes he does 
not dwell on which view he prefers [3: 280, 166]. He even gives a solution with his ijtihad without resorting to the opinion of any sect in some places [3: $219]$. In addition to the four sects, it also refers to the views of the Zaydi sect [3: 246].

Al-Zamakhshari mentions the names of Abu Yusuf and Imam Muhammad, the students of Abu Hanifa, and in some places mentions them in the form of "صاحباه" and "صاحبيه" meaning two disciples of Abu Hanifa [3: 153]. In places where the imams of the Hanafi school are in opposition to each other, AlZamakhshari behaves as follows:

- The places where two disciples opposed Abu Hanifa;

- Abu Hanifa and Abu Yusuf equally opposed Imam Muhammad;

- In very few places does he quote Imam Zufar [3: 453, 679, 215].

In the comparative analysis of the statements of the four sects, he follows the following path:

- Quotes the views of Abu Hanifa and Shafi'i, but does not state that he preferred one of the two;

- Abu Hanifa and Shafi'i narrate the issues they allied with;

- Sometimes only Imam Malik quotes but does not translate;

- Sometimes "scholars have agreed" or "scholars have given evidence" does not mention the name of the sect, but does not explicitly state which sect the ruling belongs to.

- In some cases, he refers to the representatives of the four sects without naming them "Ahl al-Hijaz" or "Ahl alIraq."

- Sometimes, after quoting four sectarian arguments on the subject, he concludes his ijtihad [3: 486, 362, 517, 367, 500, 359].

Al-Zamakhshari also used the method of "istishhad" (interpretation based on the meaning of words) to present evidence. Through this method, the author has been able to reveal the maturity of the Qur'an perfectly [2: 443].

Another method of the scholar's interpretation is "فإن قُلتَت (fa in qulta), in which the author asks a question in the form of "if you say so" as if an interlocutor was sitting on the opposite side, and responds as "I will say". This style is found in the interpretation of each verse in the work.

\section{EXAMPLES OF FATWAS ISSUED BY MAHMUD AL-ZAMAKHSHARI ON THE BASIS OF THE HANAFI SCHOOL}

1. At the beginning of Surat al-Fatihah, the author dwells on whether the Basmala is a verse from the Qur'an. According to Abu Hanifa in the Hanafi school, "basmala" is not a verse from the Qur'an. Since each work is a virtuous work with "basmala", at the beginning of each surah, "basmala" is written. Since it is not a verse from the Qur'an, the Hanafi scholars secretly recite the Basmala in the recitation of the prayer [5: 352]. Although Al-Zamakhshari cites the Shafi'i school of thought in this regard, it is possible to know that he followed the Hanafi school in this matter by describing in detail the path preferred by the Hanafis.

2. According to the Hanafis, if the word "amen" is recited secretly after the Fatiha, then it is jahr in the Shafi'i school. Al-Zamakhshari prefers the Hanafi view on this issue [3: 60].

3. Al-Zamakhshari writes that the word "منافع" (manafia) is mentioned as "nakra"

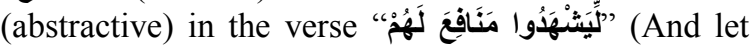
them witness the benefits for themselves).

The author dwells on the phrase, "وَيَنْكُرُوا اسنْحَ "اللَّهِ فِي أَيَّامِ مَّعُلُومَاتِ (Let them mention the name of Allah in the slaughter of the sacrificial animals that Allah has provided for them). Al-Zamakhshari says that according to Abu Hanifa, the first ten days of Dhu'l-Hijjah are meant on "إَيَّام مَّعُلُومَاتِ (certain days), and according to Abu Yusuf and Imam Muhammad, the first three days of Eid al-Adha are meant. He then states that the days of sacrifice in the Hanafi school are set for these days[1: 144], [3: 353].

The fact that Al-Zamakhshari dwells on this issue in detail and quotes only the views of the Hanafis indicates that his ijtihad in this regard was so firm that he did not find it necessary to turn to other sects.

\section{CONCLUSION}

Anyone who studies Mahmud AlZamakhshari's method of judging from the rulings of the verses will find that he was a mature jurist at the level of a mujtahid in the fields of method and furu'ul fiqh, along with the sciences of vocabulary, literature, poetry, maturity and logic. It can be said that he belonged to the Hanafi school because he relied on the views of the Hanafi school in many places in the commentary.

When the author's methods of judging on the basis of the Hanafi Madhhab, which he used in most places, were studied, it can be said that he was a mujtahid at the level of "mujtahid fi-l-masail" (ijtihad in different matters), who was the founder of the sect and his followers. 
During the time of Al-Zamakhshari, the scholars of the four sects became divided, which led to his tolerance of the sects. Due to this, it can be said that in some places the views of the representatives of other sects than the Hanafi school were more appropriate, based on the characteristics of the words in the verse. This is because the fact that a scholar who has repeatedly emphasized that he is a Hanafi is opposed to his own sect stems from the fact that the meaning of the words in the verse corresponds to which sect he belongs to. This view is also supported by the fact that it does not explicitly state the verdict on the subject matter.

It should be noted that Mahmud AlZamakhshari's statement of the views of the four sects in ruling shows that he perfectly mastered the methods and methods of these sects. The fact that he wrote Ruusu-l-masail fi-l-fiqh on the controversial issues of the Hanafi and Shafi'i sects means that he was also a mature scholar in the science of khilaf. Indeed, as Mahmud Al-Zamakhshari as a faqih, Abdulhay Al-Laknawi said: "He was one of the greatest of the Hanafi faqihs and was a high-ranking faqih."

\section{REFERENCES}

1. Umaraliev, S. (2020). Siraj al-din Ushi's teachers on hadith. ISJ Theoretical \& Applied Science, 11 (91), 142-146.

2. Ganiyev, A., \& Umaraliev, $S$. The role of zakat in the early stages of the Islamic Civilisation. EPRA International Journal of Multidisciplinary Research (IJMR), 25.

3. Mahmud Al-Zamakhshari. Al-Kashshof. - Beirut: Dar al-Ma'rifa, 2013.

4. Abdulhay Al-Laknawi. Al-Favoid al-bahiyya. Cairo: Matbaa as-saoda, 2015

5. Burhan al-din al-Marghinani. Al-Hidaya, 1 vol. Pakistan: Idara al-Qur'an and al-ulum al-Islami, 2010.

6. Dr. Ahmad al-Hufiy. Al-Al-Zamakhshari.-Cairo: al-Hay'a al-misriyya al-omma li al-kitab.

7. Shamsuddin al-Zahabi. Siyaru a'lam an-nubala, 1 vol. -Bayrut: Muassasa ar-risala, 1982. 